\title{
The similarities between Lombroso's theories on political crime and contemporary terrorism issues
}

\author{
Trevor Calafato \\ Department of Criminology, University of Malta, Msida, MSD, Malta
}

\begin{abstract}
Terrorism is considered to be a very contemporary issue and it came under the limelight only after 9/11. Yet when looking at the history of studies on terrorism and political violence, it is possible to trace back documentations from the nineteenth century. This paper looks at how Lombroso researched and studied political violence and terror in the nineteenth century. Although Lombroso is mainly known for his claims concerning the origins of criminal behaviour, he was among the first to use social science to understand anarchist political violence. In his work on anarchists, he proposed that the reasons behind anarchist violence would be found in social conditions, psychological states and religious grievances. He developed techniques to study these links, such as combining information from maps and statistical data over time to examine the likelihood of revolts occurring in particular regions of the country and to develop specific countermeasures. This study compared Lombroso's work with perspectives of academics on studies of terrorism, as well as those of policy-makers and security professionals in the implementation of security policies and potentially counterterrorism measures. This paper also compares the perspective of a current extremist actor to underlying political violence factors identified in Lombroso's work.
\end{abstract}

\section{ARTICLE HISTORY}

Received 15 September 2015 Accepted 15 March 2016

\section{KEYWORDS}

Terrorism; Lombroso; political violence; anarchists;

Gli Anarchici

\section{Introduction}

This article aims at providing an overview of the conceptualization of the contentious issues in contemporary terrorism, and comparing how Cesare Lombroso examined similar issues way back in the 1890s. This study provides a twofold contribution: a theoretical contribution to academia, as more light is shed on Lombroso's work, other than the impression of a scientist who measured skulls. Second, Lombroso's work is compared to the data extracted from interviews with 20 current professional participants involved in countering terrorism. These professional spheres included academics, policy-makers and security professionals. To provide a more complete analysis of Lombroso's work, it was also essential to interview 'Charles', a contemporary extremist who was directly linked to a terrorist actor. This comparison between the past and the present is examined in 
seven themes. Four of these themes focus on policy issues, while the remaining three looked more at the research on terrorism.

The knowledge on contemporary issues on terrorism gathered from 20 experts from different parts of the world was compared and contrasted with Lombroso's research on anarchist terrorism, titled Gli Anarchici. This work was published for the first time in 1894. Its second edition, which included additional material, was published in 1895, a few months after the first publication. Gli Anarchici consists of a study of anarchist actors, their social and psychological background and their methods of attack around the world against the backdrop of the Italian political context of the late nineteenth century. Gli Anarchici has rarely been referred to by academics because it was never translated into English but only in German (Kurella, 1895) and in French (Hamel \& Marie, 1896) within a few years. Translating this work into English was crucial for this study because it stood both as a finding and as a resource. As part of my PhD study, I set about translating this work from Italian to contemporary English, a task that took almost a year. Eventually, it was possible to create an interface between Lombroso's viewpoint and perspectives from contemporary experts, even though they are separated by a time-gap of more than a century.

\section{Laying the first stones}

While looking at pioneer criminological studies in political violence and terrorist behaviour, I came across Gli Anarchici, written by Ezechia Marco Lombroso, better known as Cesare Lombroso (1835-1909). After developing the antropologia criminale (criminal anthropology), forming the basis of criminological studies, Lombroso was acknowledged as one of the founding fathers of criminology. However, Lombroso was and still is a controversial character because of the methodologies used in his studies, particularly in L'Uomo Delinquente (Criminal Man). In this work, he explained the degenerative theory, which was sustained by physical evidence of regression and atavism in the born-criminal (il reo nato). Yet, Lombroso explored and studied various criminogenic issues in his lifetime, such as how car and bicycle mobility facilitated the commission of particular crimes, as well as the use of psychic powers (Lombroso \& Horton, 1912).

Considering his many interests in the criminal field, Lombroso was not indifferent to the sociopolitical events that affected unified Italy, including the deleterious torment of anarchist insurgencies. Anarchists and anarchism were the subjects of a number of articles that Lombroso published in different languages. However, the main piece of work on this subject was Gli Anarchici (The Anarchists) with a number of references to his other work II Delitto Politico e le Revoluzioni (The Political Crime and Revolutions). Gli Anarchici incorporated Lombroso's theories on the anarchist principles, ideologies and characters of nineteenth-century Europe. Although in this study Lombroso also considered the physiognomy of some of the most notorious anarchist figures, physical appearances did not play a major role as in the first edition of Criminal Man (1876). In Gli Anarchici, Lombroso analysed the psychological and sociological aspects of these deviant anarchist actors, and the surrounding political contexts; and criticized how draconian penal policies fuelled more violence. Data gathered from different parts of the world on anarchist terrorism facilitated Lombroso's analysis of the main catalytic issues behind political violence, as well as the modus operandi of anarcho-terrorism. 
Lombroso was never considered a scholar who contributed to the study of terrorism. However, his interest in political crime and anarchism is evident from the publications issued from 1863 to 1909 . Contrary to classical thinkers, Lombroso did not only focus on issues of crime and punishment, but also explored how social retribution deterred rational and educated individuals from committing further crimes. In seeking to answer the question, 'why does a person commit violent crimes for political ideologies?' Lombroso did not limit himself to exploring the physical anomalies in anarchists, but also investigated the mental and social milieus that could characterize 'the political criminal'.

While aiming to protect society from the occurrence of further violent crimes, fulfilling the axiom 'prevention is better than cure', Lombroso intended to help anarchist actors rehabilitate themselves in mental institutions rather than imposing excessive punishment. Thus, he recommended changes in policies and judicial practices that take in consideration each case on an individual basis, rather than presuming that every person has the 'free will' to choose good from evil. Lombroso's multilayered research methodology and scientific experiments were so unique for his times that they caused frequent academic and scientific disputes.

The historical record suggests that it took several decades for officials to accept that the Lombrosian search for the causes of crime had any relevance to their administrative tasks ... [and] Lombroso's criminology had to be extensively modified before it could be of service to policymakers and state authorities. (Garland, 1997, p. 12)

Together with the over-criticism of Lombroso's theories, language boundaries hindered researchers from studying the material published by this Italian researcher. Most criticism focused on L'Uomo Delinquente, and Lombroso's perspectives on atavism, epilepsy and the born-criminal (il delinquente nato), which stigmatized Lombroso to the extent of being rejected by numerous scholars throughout the years (Rafter, 2009). Thus, it is intellectually captivating and stimulating to investigate whether Lombroso's studies successfully explored different methods of identifying 'the political criminal' and if his methods could have formed the basis to study contemporary 'terrorist' afflictions. Additionally, it would also be interesting to find out the difference between Lombroso's recommended counterterrorism prophylaxis and those proposed today by academics and field professionals. If there are substantial converging points, could Gli Anarchici be considered a pioneering criminological study on terrorism and political violence? This paper aims at answering this question through the answers of the purposive sample of professional interviewees.

\section{Methodology}

This study aimed at comparing Lombroso's views with contemporary expert viewpoints, while seeking to understand the differences and similarities in the security practices and also in the research on terrorism. Interviews with experts from around the world were the most viable method. The interviewees had to be proficient and experienced in security provisions and research on terrorism. As a result the chosen respondents were academics, policy-makers and security professionals. The unique knowledge of this purposive sample of respondents provided first-hand and reliable information on responding to, curbing and researching terrorism. Policy-makers provided a legalistic and administrative 
perspective; security professionals expressed a practical standpoint, while the academics portrayed a theoretical outlook on the matter.

Before contacting the potential interviewees, it was imperative to take into consideration their office or position and their role vis-à-vis the phenomenon of terrorism and how they contributed in mitigating terrorism. Pre-established acquaintances within the criminal justice system helped me in identifying the purposive sample of interviewing candidates in the sectors of security and policy-making. These contacts also acted as sponsors and facilitated access, increasing the number of positive responses (Maxfield \& Babbie, 2011). Academic interviewees were chosen according to their published material on terrorism. This approach intended to secure 'an in-depth understanding of the phenomenon in question' (Denzin \& Lincoln, 2008, p. 7), which emphasized the practical, theoretical and policy differences besides validating the data (Mason, 2001).

Of the 72 potential respondents, only 65 elite subjects replied when contacted. Out of these 65 potential interviewees, I managed to interview only 20 because some declined to participate and others did not answer my emails and telephone calls. Around a 150 emails were sent, and these included first-contact emails, reminders and those confirming appointments for the actual interviews. The final group of respondents consisted of six policy-makers, seven academics and seven security professionals. The last group included law enforcers, army officers, intelligence analysts and prison officials, among other security entities. Similarly, in preparation for the Handbook of Terrorism Research, Schmid (2007, p. 16) also contacted 'hundreds of experts, [and only] 90 of them answered ...'

'Any research on a criminal justice institution, or on persons who work either in or under the supervision of an institution, normally requires a formal request and approval' (Maxfield \& Babbie, 2011, p. 302). Obtaining approval to access designated representatives from the respective organizations of these respondents was indispensable. Approvals had to be pre-arranged mainly with security practitioners and policy-makers before any interview could take place. The process to gain approval can be frustrating, complex and confusing, because hierarchical formalities and informal internal cultures hamper a smoother progression and practical approach (Maxfield \& Babbie, 2011). Gaining formal access can take months and yet it does not guarantee that the chosen candidate/s will accept or agree to be interviewed (see Horgan, 2011). According to Maxfield and Babbie (2011, p. 302), 'the best strategy in gaining access to virtually any ... formal criminal justice organization is to use a four-step procedure: sponsor, letter, phone-call, and meeting'. This four-step procedure guided the methodologies used in gaining access to the 20 interviewees. Finding sponsors in highly ranked positions was fundamental to gain access to a number of interviewees. Sponsors advised on whom to contact and in some cases introduced me to other key officials, avoiding being subject to excessive gatekeeping (Jupp, 2003; Maxfield \& Babbie, 2011).

When no sponsors were available to help finding access, I started by sending emails and letters. If after three emails there was no reply, respondents were removed from the list. Negative responses created difficult moments and generated doubts on whether the necessary number of interviewees would be secured in time. Gaining access to certain police agencies without sponsors to bypass the extensive gatekeeping of security and law enforcement entities is challenging and only five respondents wrote back (Holdaway, 1983, as cited in Jupp 2003, p. 59). Contacting academics researching terrorism and related 
security matters was less demanding because academic journals helped in identifying potential academic respondents.

An even harder task than interviewing elite respondents was setting up interviews with persons suspected, accused or convicted of terrorism (Maxfield \& Babbie, 2011). After failing to contact a former or active extremist for almost a year, this part of the research had been discarded. The only successful attempt was to contact an extremist directly through his own website. Following a widely reported terrorist attack, the media spread the contact details of this individual, whom I called 'Charles' (not his real name), and provided me with the possibility of an opportunistic interview, as commonly happens in terrorism research (Dolnik, 2011; Silke, 2001).

The process by which sense was made of the verbal input derived from all the interviews was the foundational method of thematic analysis (Braun \& Clarke, 2006). Thematic analysis is a flexible method that pays attention to the qualitative aspects of the material being analysed (Joffe \& Yardley, 2004). This method indicates similar or contrasting views and themes within the same group as well as in-between groups. Thematic analysis offers the possibility to identify manifested patterns in the gathered data and also allows the researcher to interpret latent themes that are implicit in the data (Braun \& Clarke, 2006; Daly, Kellehear \& Gliksman, 1997; Fereday, 2006; Joffe \& Yardley, 2004; Rice \& Ezzy, 1999). Salient parts of the data corpus were analysed in seven themes, which are also explored and discussed in contrast with Lombroso's work. These seven themes are, namely (1) definition of terrorism; (2) security and terrorism risk management; (3) counterterrorism and policy-making; (4) imprisonment and rehabilitation; (5) identifying terrorism research; (6) researching methods in terrorism and (7) profiling terrorists.

\section{Definition of terrorism}

The majority of acknowledged authorities in the field of terrorism struggle with defining the term 'terrorism' (English, 2009; Gupta, 2008; Hoffman, 1998, 2006; Jackson, 2011; as cited in Bryan, 2012; Townsend, 2002; Wilkinson, 2001, 2006a, 2006b, 2011). As Banks $(2013$, p. 220) stated, the 'fundamental to any discussion of terrorism is an understanding of the meaning and scope of the term'. The definition of terrorism is a multifaceted political issue. For example, some researchers dismiss or ignore the existence of state terrorism and consider terrorism as solely a crime by non-state actors (Banks, 2013). The definition of terrorism is still a contested territory (Hoffman, 2006), something that I refer to as "knowledgeable incoherence'. The first question queried 'How would you describe a "terrorist"?' without relying on the word 'terror' or its derivatives.

The three respondent groups were mindful of the complexities in defining terrorism and there was something of a consensus regarding the problematic definitional contours. However, having to avoid the use of the word 'terror', the respondents resorted primarily to the term 'violence'. This applied to all three groups. Policy-makers and security professionals were very inclined to use the term 'violence', particularly with regard to non-state actors. The academics highlighted the labelling that is inherent in the word 'terrorism', together with underlying political objectives as motivators of violence. The respondents used the word 'violence' 55 times. In the 13 responses of policy-makers and academics, the word 'violence' was used 44 times (policy-makers - 13 times; academics - 31 times). In contrast, 6 of the 7 security professionals used this term 
only 11 times. To a greater extent, the respondents considered non-state actors as the 'terrorists'.

Similarly, Schmid and Jongman (1988, pp. 76-77, as cited in Schmid, 2011) observed that from the identified 109 definitions of 'terrorism', 83.5\% used the terms 'violence' and 'force'. The overall results reflected Wilkinson's (2001, pp. 12-13, as cited in Banks, 2013) description of terrorism as 'the systematic use of coercive intimidation, usually to service political ends'. A policy-maker explicated that terrorists deliberately use 'violence for political purposes or in relation to a political objective'. As Banks (2013, p. 220) stated, 'terrorism is a method or means of achieving an objective'. Terrorism encompasses a myriad of phenomena that necessitate individualized analytical tools to differentiate between regime terror and non-state actors that make up domestic or international terrorism (Wilkinson, 2012).

Terrorist groups and individuals believe their struggle is legitimate. Consequently, terrorist violence and political motivations cannot be understood unless the surrounding context is taken into consideration (Bryan, 2012). One of the policy-makers stated, 'terrorism varies according to the country, time, and who is the terrorist'. This conforms to Hoffman's (2006, p. 37) portrayal of the terrorist as 'fundamentally an altruist' as well as to Kellen's (1982, p. 10) belief that a 'terrorist without a cause (at least in his own mind) is not a terrorist'. Nonetheless, the term 'terrorism' creates a demonization of the actor without any distinction with regard to motivations, modus operandi and regime policies, provoking a counter-terror impetus of violence (Banks, 2013; Bryan, 2012; Hoffman, 2006; Schmid, 2011; Wilkinson, 2012). The academic respondents indicated that labelling terrorists as dangerous individuals renders vague their political motivations, and hinders the understanding of their ideologies. 'Rejectionists argue that the term [terrorism] should be abandoned in academic research because it is now too ideologically tainted to be used as the basis for objective or rigorous research' (Jackson, 2011, p. 117). In fact, critical terrorism studies argue in favour of abandoning the concept of terrorism (Wilkinson, 2012).

The results obtained from the interviews showed the potential usefulness as well as the difficulties of finding a suitable definition of 'terrorism' (Schmid, 1997, as cited in Young, 2006; Schmid 2004, 2011). The trend is to focus on non-state actors, while it is almost habitual to ignore the politics and the relevance of 'specific political, social, economic and cultural background to a terrorist conflict' (Wilkinson, 2012, p. 17). In essence, the results obtained highlight that terrorism is synonymous with the justified use of violence (from the actor's perspective) to achieve political changes. Demonizing and politicizing the term 'terrorism' result in labelling individuals and groups, but exonerating governments from being considered 'terrorists'. Political issues interfere with achieving a neutral definition and hinder the possibility of finding a common definition of terrorism that suits policy-makers, security practitioners and academics.

Cesare Lombroso was among the first researchers who attempted to understand political violence, its underlying ideologies and the individual actors involved in anarchist terrorism, and also issued a definition. At the time the definition of terrorism was not contested, but penologists were reluctant to recognize the existence of political crime. Lombroso and Laschi (1892, as cited in Daly, 2002, p. 68) defined political violence as 'any violent harm caused to laws established by the majority to preserve the political, economic or social system that it desires'. In Gli Anarchici, Lombroso's (1895) intentions 
were to understand the causes, motivations and ideologies of anarchists and contemplated that the anarchists' use of violence was a reaction to political, economic and social grievances.

While the main focus of the interviewees' definition was on the individual non-state perpetrator, contrastingly Lombroso tried to create an all-encompassing perspective. When studying anarchists, Lombroso did not avoid exploring the terror imposed by the state besides the individual anarchist. His ambition was to stop the use of violence to reclaim justice. He pursued the understanding of both anarchist actors and state actors, as was the case of the academic respondents. As Wilkinson (2012) and the academic respondents focused on a contextual inquiry, analogously Lombroso (1895, pp. 6-8) aimed at identifying those social and economic conditions that attracted what he called 'altruistic fanatics' to engage in extremely violent behaviour. In agreement with Ferrero, Lombroso (1895, p. 8) considered religion as one of the main attractors for extremists who engage in violence and described it as a 'lightning conductor of fanaticism'. When exploring the influencing factors, Lombroso (1895, p. 111) also considered Nicolo Machiavelli's and Benjamin Franklin's writings to explain that government mismanagement brought seditions that enforced extremist ideologies, such as anarchism. To describe the effect of politicians and privileged classes that ignored these struggles and grievances, Lombroso (1895, p. 16) referred to 'highly conscientious people like Tolstoi, Richet, Sergi, Hugo, Zola, Nordau, De Amicis' [sic].

\section{Security and terrorism risk management}

'Modelling approaches for assessing terrorism risk have been an outgrowth' (Chatterjee \& Abkowitz, 2011, p. 1133). Speculations indicate that the terrorist threat levels are inflated to suit political agendas and gain more funds (Jackson, 2011; Mueller, 2006). Thus, this research aimed at answering 'what is the level of the terrorist threat? And how do people react to this threat level?' The majority of the respondents indicated that the terrorist threat is from a medium to low range. However, it is difficult to predict how the public would react to a real terrorist threat. The responses indicated three possibilities of how the public would react, namely increased vigilance, panic or complete ignorance of the threat levels. However, these reactions would vary again according to public sensitivity, experiences and psychological distress caused by recent terrorist events (Lerner, Gonzalez, Small, \& Fischhoff, 2003; Schuster et al., 2001). These aspects make the management of security and the risk of terrorism more difficult to assess (Kunreuther, 2002). Security personnel and law enforcers tend to be quite secretive on terrorism-related matters. On the contrary, academics encourage transparency and presume that the public will assume a more active role in 'singling out individuals or groups that are more at risk of becoming terrorist actors'. Nonetheless, behaviours vary with geographical and sociological differences. As one of the security professionals stated, 'Dutch persons are policed in different ways than Spanish society is policed'.

Gli Anarchici identified the main sufferings and how anarchist ideologies interpreted them to inspire fanatics to get involved in extremist actions. To understand the threats posed by anarchists and design adequate countermeasures, Lombroso consulted sources from around the world. To find more information about the background and abilities of these anarchist actors, Lombroso $(1895$, p. 19) referred to statistics from the Parisian 
police force that recorded the different employments and offices held by anarchist actors. Economic grievances suffered by the majority were the main catalyst of anarchist violence and according to Lombroso, this political violence was a protest against the superior classes. This work also showed that the anarchists responsible for these violent actions were educated, professionally employed and with a high economic status.

Although Lombroso never identified the threat level of anarchist terrorism, he expressed that when governments did not respect the rule of law and human rights, these stimulated violent reactions. Lack of protection and social well-being were consequences of despotic and dishonest governments that used public money for personal interests. Administrative financial abuses by governments increased the political dominion with the use of brutal military force and economic hardship on poor citizens (Lombroso, 1895, pp. 24-25). Lombroso also discussed that authorities used the anarchist threat to sustain their agendas. Likewise, the interviewees discussed how heightened threat level energizes hidden agendas of security services that gauge, assess and decide this risk. Most respondents explained that extremely high threat levels were perceived to be part of a political game that sustained new policing schemes and secured future resources for prescribed agendas. Critical terrorism studies consider that inflated levels of the terrorist threat induced governments to gain more power with the premise of safeguarding their countries (Jackson, 2011). On parallel thoughts, Lombroso stressed that the existence of policing and military entities would be in danger if major threats were to be extinguished:

Let us imagine an army in a country where there are no reasons, or fear, of civil or external war. The army will either provoke war or, if this does not succeed, the army will disband. A police force that has no crimes to investigate and no criminals to arrest will invent crimes and criminals, or the police will cease to exist. (Lombroso, 1895, p. 27)

Similar to academics in critical terrorism studies, some of the interviewees and Lombroso concord that security entities need to keep the struggle against threats like terrorism alive and the threat levels elevated as if it is only a question of when and not if there is a next attack. However, whether the threat levels are a political game or a reality, terrorism remains difficult to assess and manage, and so security entities should aim to be prepared for the worst-case scenarios even when the threat is not considered as elevated (Kunreuther, 2002).

\section{Counterterrorism and policy-making}

Hostilities limit constitutional rights and freedoms, and erode democracies. Identifying erroneous and misguided policies, and amending the mistakes without demonizing the 'others', reduces the feelings of isolation experienced by minority groups and minimizes the possibility of conflicts (Fraihi, 2008). 'While the West sees a threatening Islam looming, large majorities in Muslim countries are convinced the West has declared war on them and has decided to keep them in a permanent position of subordination' (Coolsaet \& de Swieland, 2008, p. 167). Dividing the world into 'Us' defending ourselves against a threatening 'Them' eliminates the possibility of nuance or tolerance (Ramadan, 2006). Communities that perceive the police as the enemy do not trust law enforcers. This creates extensive lacunae in intelligence on underlying grievances and trends of self- 
radicalization, self-recruitment as well as the politicization of extremist agendas (Coolsaet \& de Swielande, 2008; Sageman, 2004; Taarnby, 2005).

When inquiring 'Who has the onus of countering and controlling (or preventing) terrorism?' the respondents pointed mainly towards national security agencies and government entities as responsible bodies. However, when it comes to controlling terrorism, the interviewees indicated that it would be ideal to create a network that includes the various law enforcement and security entities, non-governmental organizations, academics and the general public. Though Lombroso never mentioned a 'multi-agency approach', he wrote that the government, law enforcement and the social context were key elements in creating a network that defies extremist anarchist ideologies. Lombroso explicated that government-implemented draconian methods were not successful in controlling anarchism. Violent methods created more martyrs and these attracted more people to the anarchist cause. Lombroso recommended more non-violent policing cooperation and countermeasures. While referring to Desmarets (1833), Lombroso $(1895$, p. 70$)$ highlighted that the Napoleonic police were keeping youths between the ages of 18 and 20 years under surveillance. Additionally, Lombroso $(1895$, p. 121) recommended the police to take pictures of anarchist militants, report the movement of dangerous individuals and lock anarchists in asylums or perpetually imprison them on distant islands. To make the public abandon anarchist ideas, Lombroso proposed giving the public the possibility to protest against anarchist violence and create an anti-anarchist movement that represented the majority of the populace. However, these socialist methods went against the belief of '(quite a few) political thugs that believe[d] that socialism [was] the faithful ally of anarchy; it [was] instead the greatest enemy and the best prevention' (Lombroso, 1895, p. 129).

While explaining different ways to control and prevent terrorism, the interviewees also proposed policy changes in the education and other social provisions to improve the sense of integration and resilience. These recommendations aimed at providing alternative ways to achieve one's goals without using terrorism. In Gli Anarchici, Lombroso (1895, p. 22) also contended changes in religious and particularly classical education because these lauded violence and revolutionary individuals. Lombroso (1895, p. 125) denoted that religion was the stimulus behind the crusades and did not exclude the possibility that anarchist ideologies and concepts were derived from religious writings like those of Saint Thomas Aquinas and Father Juan de Mariana. In curing the anarchist 'virus', Lombroso (1895, p. 128) targeted classical education that justified violence and made it an ideal that encouraged anarchism. Consequently, Lombroso (1895, p. 128) recommended replacing classical education with manual labour, the study of positivist sciences and the study of languages, rather than imposing repressive laws.

The respondents considered controlling radicalization to be key in addressing the roots and underlying grievances of the contemporary problem of terrorism. 'Radicalization' was not in Lombroso's work, but he investigated the influences that triggered the process of groupthink, and how these pressures stimulated a person's thoughts and behaviour to ultimately engage actively in anarchist terrorism. This process of engagement in extreme violent behaviour is similar to those discussed by contemporary researchers (McAllister \& Schmid, 2011; Silke, 2003). To sustain this theory, Lombroso examined the contextual hardships, family and criminal history, and documented individual experiences, behaviours, mental illnesses, speeches and writings of anarchists. His results established that anarchism passed through a gradual purificazione (purification) (Lombroso, 1895, 
p. 116). The first heroes of this extremist ideology were born-criminals who were thirsty for blood, like Ravachol. But later characters like Valliant and Henry were of a different kind and did not exhibit born-criminal characteristics. The fulcrum of Gli Anarchici was Caserio, who changed from an honest person into the fanatical anarchist who assassinated French President Carnot. Anticipating some of the latest radicalization studies, Lombroso (1895) was fascinated by how honest and law-abiding youths like Caserio could be attracted to extremist anarchist ideologies and become indoctrinated. He compared this fanatic extremism to the assassins in the Middle East who became devoted followers of the Old Man of the Mountain (see Daftary, 2008).

\section{Imprisonment and rehabilitation}

'Over 100,000 convicted and suspected terrorists are languishing in penitentiary and detention centres from Europe to the Middle East and Asia' (Gunaratna, 2011, p. 66). In 2011, 484 individuals were arrested in Europe for terrorist-related offences and 316 individuals (of whom 40 were women) were handed down a verdict (Europol, 2012). In 2010 (when the interviews took place), a respondent from the security professionals cohort stated that 'in the Netherlands only around ten prisoners [were] convicted of terrorist acts', whose crimes varied from planning an attack to murder. Transparency and proportionality are fundamental when it comes to sentencing terrorists and designing counterterrorism policies (Finn, 2010).

When asking the respondents 'what kind of punishment would they impose on someone accused of terrorism?' most respondents believed in the use of incarceration, although they did not exclude the possibility of rehabilitation and reintegration back in society. 'Prisons have long been places where extremist ideology and calls to violence could find a willing ear and conditions are often conducive to radicalization' (Cilluffo \& Saathoff, 2006, p. i). Prisons play a major role in the incubation of radical and militant movements (Neumann, 2010, pp. 7-8). Consequently, 'mere punishment through imprisonment is not enough to permanently reform and facilitate their reintegration into society upon release' (Gunaratna, 2011, p. 67). Imprisonment should include education and reform. De-radicalization of prisoners and disengagement from terrorism are frequently discussed, yet empirical data are scarce (Horgan, 2009; Useem \& Clayton, 2009).

Minimal use of extreme harsh treatment, imprisonment and rehabilitation were also among the main arguments discussed in Gli Anarchici. Lombroso discussed the punishment and treatment of political criminals even in I/ Delitto Politico, published about five years before the second edition of Gli Anarchici. In the nineteenth century, regicides (killings of kings) and deputicides (deputaticidio) (killings of government deputies) were considered among the gravest political crimes (Lombroso, 1895, p. 133). To counter these political crimes, some states adopted harsh legislative punishments. Political offenders who were 'found guilty of committing grave regular crimes were often punished more harshly than regular criminals committing the same crimes' (Daly, 2002, p. 68). Excessive force and violence against anarchist actors served as gratuitous help because this reaction created 'martyrs' who would render them icons and idols of sympathizers (Lombroso, 1895).

Anarchist actors used the state's drastic reactions to become 'martyrs' of their ideology. Rather than committing suicide, these actors would attempt to assassinate heads of state 
or monarchs, and sometimes even manage, for which the punishment was a mandatory death sentence. Lombroso concluded that the purpose of these individuals was to commit suicide and referred to the theories of 'indirect suicides' (suicide indiretti), by Maudsley, Esquirol and Krafft-Ebing. Fanatical ideologies give valuable reasons to commit violent actions and 'the more bizarre and absurd an idea is, the more mad, mattoids and hysterics drag behind it' (Lombroso, 1895, p. 98). For instance, the anarchist Ravachol was so idolized by his sympathizers that they even dedicated anthems to him and his death served as propaganda to attract more sympathizers towards anarchist terrorism (Lombroso, 1895, p. 114). Another example is the massacre of the Babi movement in Persia in the mid-1800s, which showed how such extremism was used to attract more recruits (Lombroso, 1895, p. 73; see also Mottahedeh, 1998).

In both /I Delitto Politico and Gli Anarchici, Lombroso recommended punishing anarchists and political criminals using non-violent methods. These punishments entailed deportation, solitary confinement, exile, pecuniary penalties, suspension from or loss of offices (in case of public officers) and removal of political rights. These punishments had to be imposed for crimes that range from murder, treason and espionage to injuries to head of states, armed revolts, labour strikes and insults to a monarch or members of parliament (Calafato, 2013). Lombroso wanted to indicate that there are other ways to treat anarchists without resorting to special treatments and capital punishment. Lombroso's liberal perspective aimed at the implementation of non-violent methods and recommended rehabilitation from fanaticism. This brings Lombroso's conclusions close to the responses of the academics and the security professionals, who favoured punishment and rehabilitation rather than the use of coercive methods.

Removing draconian laws and implementing non-violent measures restrain the 'anarchist hydra' (idra anarchica), as later on sustained by Arquilla and Ronfeldt (2001). Gli Anarchici solicited the authorities to follow the administration of British Prime Minister Gladstone, and avoid generating more violence (Lombroso, 1895, p. 116). Lombroso (1895, p. 137) considered research on the root causes of fanaticism as the cure to this scourge. This study indicated that anarchism tended to occur where there was bad government administration, in the same way cholera tended to be more frequent in poor and dirty neighbourhoods:

Come si vede il colera colpire di preferenza i quartieri più poveri e più sudici della città, e quindi indicarci ove debbansi più portare le nostre cure profilattiche, così l'anarchia infierisce nei paesi meno ben governati, e perciò la sua comparsa potrebbe essere, in mezzo all'apatia delle masse o degli uomini politici, indizio di cattivo governo -e stimolo vivo a migliorarlo. ${ }^{1}$ (Lombroso, 1895, pp. 135-136)

\section{Identifying terrorism research}

Terrorism research is characterized by 'a persistent set of weaknesses [and] an increasing number of theoretically rigorous and critically oriented studies' (Jackson, 2009, p. 171). When questioning 'Which is the best approach to study terrorism?' the interviewees looked at combining academic research with intelligence analysis to ensure a better understanding of terrorism. Contextual inequities, grievances, social and economic issues, psychological matters and lack of political freedom are some of the causes of terrorism (see Berrebi \& Klor, 2006; Gupta \& Mundra, 2005; Hafez, 2007, as cited in Gupta, 
2012; Kydd \& Walter, 2006, as cited in LaFree et al., 2012; Pape, 2003). Terrorism is a confluence of factors and causes and the respondents emphatically stressed the need for all and sundry to understand this phenomenon. Terrorism does not exist in a vacuum and studies on root causes determine adequate counteractions (Bjørgo, 2005; see also Gurr, 1970; Reich, 1998; Sinai, 2008; Smelser \& Mitchell, 2002). No one of the 20 respondents considered terrorist actors as insane or psychologically wired differently from the rest of the population, as attested by a number of studies (Gupta, 2012; Horgan, 2005a, 2005b; McCauley, 2007; Merari, 2005; Post, 1984, 1990; Post, Sprinzak, \& Denny, 2003; Silke, 2003; Taylor, 1988; Taylor \& Quayle, 1994). But the lack of understanding of terrorism keeps on encumbering studies and researchers who conceive terrorism as a form of madness. For instance, Silke (2004) reported that after 9/11 Laqueur stated:

Madness, especially paranoia, plays a role in contemporary terrorism. Not all paranoiacs are terrorists, but all terrorists believe in conspiracies by the powerful, hostile forces and suffer from some form of delusion and persecution mania... The element of ... madness plays an important role [in terrorism], even if many are reluctant to acknowledge it. (Laqueur, 2001, p. 80 , as cited in Silke, 2003)

As the respondents envisaged a mix of social sciences with intelligence, analogously Lombroso used an eclectic approach to create a holistic picture of the causes of anarchism. Lombroso $(1895$, p. 20$)$ described that anarchism was a consequent reaction to 'profound evils that corrode our vital organs such as the pellagra, alcoholism, superstition, regulated injustice and ignorance in school subjects'. Various causes modify the trajectories of individuals before engaging in terrorist activities (Taylor \& Horgan, 2006). Together with political conflicts, economic depressions and social difficulties, Lombroso studied anarchist personalities, their backgrounds and psycho-behavioural reactions. He identified different anarchist behaviours and mental conditions, as the chapter titles imply: epilepsy and hysteria, crazy individuals, mattoids, indirect suicides, crimes of passion, altruism and neophilia. Lombroso theorized that anarchist reactions were also determined by individual traits, attitudes and behaviours. For instance, mattoids 'expressed less evil and minor energies when compared to born-criminals, as they completely lacked evil practice and shrewdness' (Lombroso, 1895, p. 61).

With the case study of Caserio, Lombroso aimed at showing that not only born-criminals were attracted to the anarchist ideology. The progression from a criminal personality like Ravachol to an honest fanatic like Caserio highlighted the central role of indoctrination in political crimes of passion (Lombroso, 1895, p. 72). Lombroso associated anarchists with mental conditions, diseases and mental dysfunctions, and studied the environments they lived in. Caserio did not suffer directly from pellagra, a vitamin deficiency disease, but he witnessed the poor conditions experienced by peasants who suffered from this disease in northern Italy. These contextual issues together with the sense of revenge, alimented by the killing of previous anarchists, motivated Caserio to adopt an anarchist ideology and to commit a murderous act.

In Gli Anarchici, the aim was to answer 'how and why would an individual who, in a different time and space, would have been a robber or a pirate or a good person, has now become an anarchist, in the worst sense of the word?' (Lombroso, 1895, p. 7). As the interviewees emphasized the contribution of mixing academic research with intelligence, Gli Anarchici looked at economic fanaticism, extreme altruistic tendencies and 
manipulated religious beliefs, together with the excessive reactions by authorities and the unjust treatment by social institutions. Consequently, Lombroso (1895, p. 23) recommended that modern man should renounce to violence and abide by the principle that 'violence is always immoral, even when it is directed to reject other violence'. Violent reactions against innocent victims and anarchists were stronger than any form of propaganda. Similarly, the interviewees also supported the adoption of a non-violent approach to mitigate terrorism, at both the national and international levels. Gli Anarchici showed that countries that were not involved in coercive actions were less affected by anarchism and similar political crimes (Lombroso, 1895, p. 121).

\section{Researching methods in terrorism}

Different academic fields characterize research in terrorism (Gordon, 2010; Schmid \& Jongman, 1988). When querying 'Which academic disciplines provide the most comprehensive understanding of terrorism?' almost all respondents (16 of 20) concurred that the best approach to study terrorism is to combine different academic disciplines. 'Problems in understanding terrorism bring us to adopt a multidisciplinary approach, which provides us with better understanding', stressed the academic respondents. As Gordon (2010, p. 440) explicated, the fragmented character of terrorism created the foundation for 'a cohesive discipline'. The findings from the interviews portrayed terrorism studies not as a discipline, but as a subject consisting of research from different academic fields. Schmid and Jongman (2008, p. 178) discussed some of the main typologies and academic disciplines that studied different aspects of terrorism. A multidisciplinary research approach was considered necessary by the interviewees, to overcome some of the numerous obstacles encountered in researching terrorism, making it more academic and less journalese. Moving away from the overdependence of secondary-sourced terrorism research (Crenshaw, 2001; Horgan, 2007; Silke, 2004), and to adopt more sophisticated research techniques, promoted desk-based terrorism research to evidence-based studies, which provide more in-depth details about the terrorism phenomena (Berko, 2007; Horgan, 2009).

Research on terrorism is full of controversial issues. Methodological, theoretical and epistemological matters hinder terrorism studies from being recognized as a scientific discipline (Gordon, 2010; Sinai, 2007) and expose this subject to numerous challenges and criticisms (Gunning, 2007; Stump \& Dixit, 2013). After all, even the history of terrorism research is uncertain. Gordon (2010) dates the history of terrorism research back to 1965, but Bonanate, Oldani, and Migliorino (1979) recorded the first two books on terrorism three decades before, namely Sottile (1938) and Waciorski (1939). After prompting the discussion on the multidisciplinary approach respondents would adopt in studying terrorism, this study explored the contributions of different research methodologies when it came to researching terrorism and identifying potential future attacks. The answers to this question were divided in two discussions. The first one presented the respondents' perceptions on the uses and limitations of statistics when researching terrorism and predicting future attacks. The second discussion evaluated the use of interviews and the weaknesses associated with interviewing individuals involved or associated with terrorist acts or actors. Whether analysing statistics or face-to-face interviews with extremist actors, 'social science researchers typically have to work with very "noisy" data where there are 
potentially a vast number of factors exerting an influence on any one behaviour, event or trend' (Silke, 2008, p. 35). Numerous academics value the use of first-hand interviews with terrorists (e.g. Alonso, 2006; Baeyer-Kaette, Classens, Feger, \& Neihardt, 1982, as cited in Horgan, 2011; Berko, 2007; Bloom, 2005; Dolnik, 2011; Horgan, 2008, 2009; Jager, Schmidtchen, \& Sulllwold, 1981, as cited in Horgan, 2011; Jamieson, 1990, as cited in Horgan, 2011; Post et al., 2003; Stern, 1999; Taylor \& Quayle, 1994). Zulaika (1996) also expressed a willingness to join terrorists to gain a more thorough perception of underground organizations.

The multidisciplinary approach is one of the most compelling connections between the respondents' answers and also in Lombroso. In Gli Anarchici, Lombroso (1895, p. 5) explained how the psychiatric-anthropological method was applied to the study of the hottest issues with empirical impartiality. Lombroso used various academic disciplines to sustain his arguments. Political science, anthropology, medicine, sociology, psychology, psychiatry and history are among the disciplines that could be easily identified in his criminological analysis of anarchism. After perusing and combining data obtained from different fields, Lombroso was in a position to assess (Italian) contemporary politics by comparing them to other countries from various parts of the world. This combination of political sciences and anthropology was essential for him to identify contextual issues that made people more prone to resort to revolutionary activities and political violence. In this case, the identified catalysts were namely political corruption and abuse, which led to poverty, malnutrition and disease. For instance, Lombroso (1895, p. 78) described the economic difficulties experienced in the Lombard region as worse than those of Roman slaves.

Fields such as sociology, psychology and psychiatry were fundamental in Lombroso's analysis of the sociological contexts as well as the individual characteristics that motivated a person to endorse anarchist ideologies and to become involved in violent attacks on its behalf. For instance, when presenting cases of extreme altruism, Lombroso (1895, p. 87) explained that Hamon decided to resort to anarchism only for solidarity with hospital patients who were in need. On the individual level, Lombroso looked for traits that facilitated one's attraction to anarchism and political violence for instance: epilepsy, altruism and neophilia.

The three groups of respondents considered statistics as having a limited value, and while the interviews with terrorist actors are 'unreliable'. Lombroso did not abide to particular research standards and did not discuss research methodologies used by him or other researchers, thus creating serious doubts and weaknesses in his research methods (Gibson \& Rafter, 2006). However, to sustain his arguments and create a complete picture of this phenomenon, Lombroso used results obtained from both quantitative and qualitative approaches. Lombroso used statistics originally published by Dubois (1893) to create a profile of anarchist actors in France, even though he considered these statistics as 'not very accurate and objective' (Lombroso, 1895, p. 19). In the penultimate chapter of the second edition of Gli Anarchici, Lombroso referred to other statistical analyses that correlated the effect of high temperatures in different seasons in relation to the number of revolutions over different time periods and countries, as indicated in Table 1 (Lombroso, 1890, as cited in Lombroso, 1895, p. 105). Another statistical analysis presented a geospatial distribution of revolutions in Europe between 1791 and 1880 on a map (Figure 1). Lombroso did not include much detail as from where and how the data were collected, but declared experiencing difficulties in gathering information 
Table 1. The number of revolts in different eras and countries.

\begin{tabular}{|c|c|c|c|c|c|c|c|c|c|c|c|c|c|c|c|c|}
\hline & \multicolumn{6}{|c|}{ Ancient times } & \multicolumn{2}{|c|}{ Middle ages } & \multicolumn{5}{|c|}{ Modern times - America } & \multicolumn{3}{|c|}{ Modern time - Europe } \\
\hline Spring & & & & 31 & & & & 14 & & & 76 & & & & & 42 \\
\hline Summer & & & & 44 & & & & 28 & & & 92 & & & & & 67 \\
\hline Autumn & & & & 20 & & & & 18 & & & 54 & & & & & 94 \\
\hline \multirow[t]{2}{*}{ Winter } & & & & 20 & & & & 16 & & & 61 & & & & & 92 \\
\hline & Spain & Italy & Portugal & $\begin{array}{l}\text { Turkey } \\
\text { (European } \\
\text { side }\end{array}$ & Greece & France & $\begin{array}{l}\text { Belgium and } \\
\text { the } \\
\text { Netherlands }\end{array}$ & Switzerland & $\begin{array}{c}\text { Bosnia, } \\
\text { Herzegovina, } \\
\text { Serbia, Bulgaria }\end{array}$ & Ireland & $\begin{array}{l}\text { England } \\
\text { and } \\
\text { Scotland }\end{array}$ & Germany & $\begin{array}{l}\text { Austria - } \\
\text { Hungary }\end{array}$ & $\begin{array}{l}\text { Sweden, } \\
\text { Norway } \\
\text { and } \\
\text { Denmark }\end{array}$ & Poland & $\begin{array}{l}\text { Russia } \\
\text { (European } \\
\text { side) }\end{array}$ \\
\hline Spring & 23 & 27 & 7 & 9 & 6 & 16 & 7 & 6 & 7 & 6 & 5 & 7 & 3 & 4 & 6 & 3 \\
\hline Summer & 38 & 29 & 12 & 11 & 7 & 20 & 8 & 5 & 3 & 3 & 9 & 11 & 6 & 4 & 1 & 0 \\
\hline Autumn & 18 & 14 & 4 & 5 & 3 & 15 & 6 & 3 & 1 & 3 & 5 & 4 & 7 & 2 & 2 & 2 \\
\hline Winter & 20 & 18 & 6 & 3 & 3 & 10 & 2 & 10 & 4 & 3 & 4 & 3 & 2 & 2 & 1 & 1 \\
\hline
\end{tabular}

Source: Adapted from Gli Anarchici (p. 104), by Lombroso (1895) and from /l Delitto Politico (p. 49), by Lombroso and Laschi (1892).

Note: The highest values are marked in bold. 


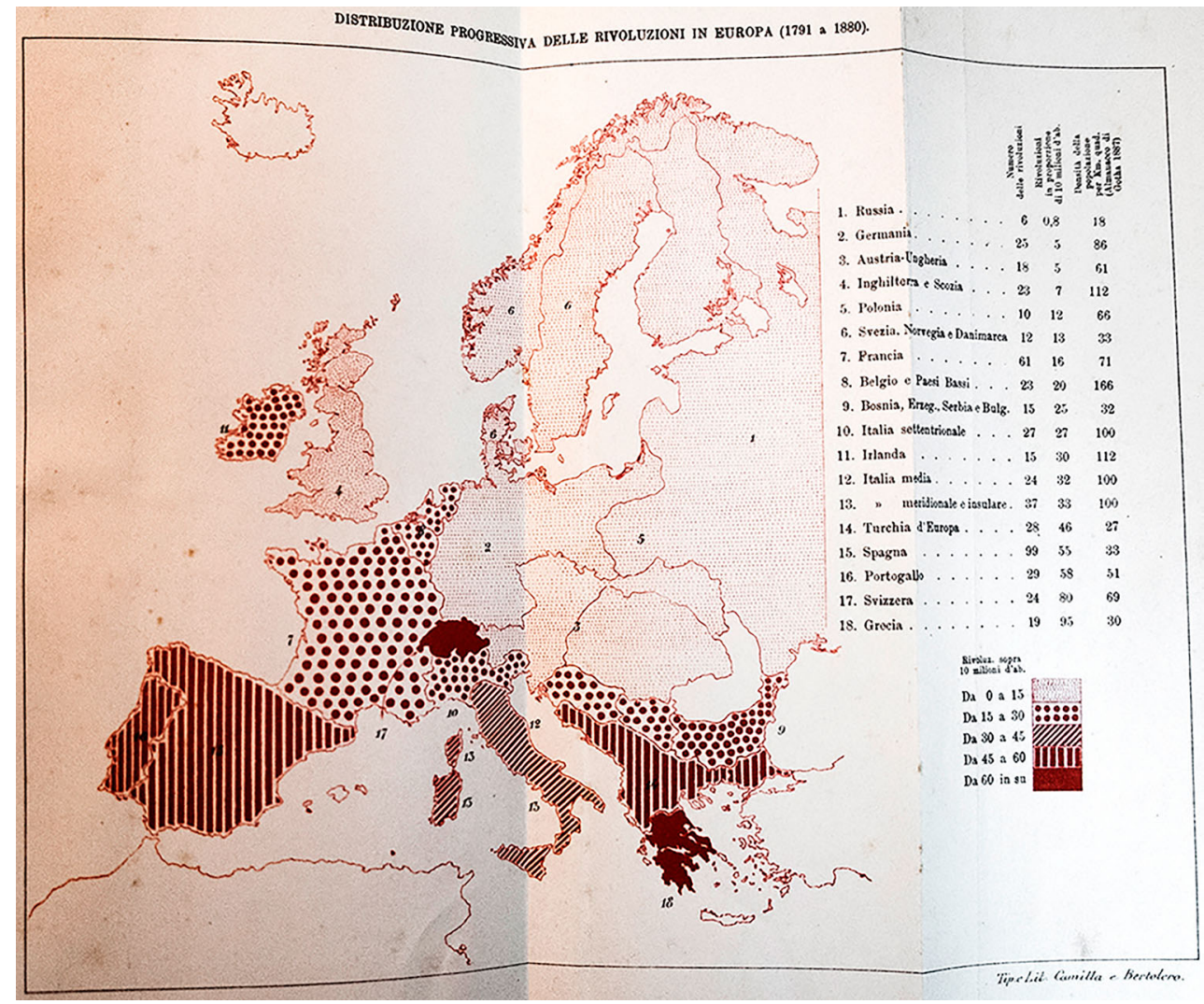

Figure 1. Mapping the distribution of revolutions in Europe (1791-1880). Adapted from II Delitto Politico (p. 558), by Lombroso and Laschi (1892).

from Switzerland and Ireland due to changes in governments and constitutions. Table 1 and Figure 1 showed that 'apart from some rare exceptions the highest number of revolutions occurred in warm months', particularly in southern European countries (Lombroso, 1895, pp. 105-106).

The qualitative analyses in Gli Anarchici included anarchist literature, speeches, newspapers and historical documents. Lombroso looked thoroughly at the discourse of anarchist actors, and examined the jargon used in the lyrics of the anarchist songs and the defence speeches of Ravachol and Henry. The discourse analysis of Ravachol's and Henry's speeches served to distinguish the egoistic and born-criminal nature of Ravachol from the more altruistic ideologies of Henry (Lombroso, 1895, pp. 88-94). To further expose the anarchist ideologies, Lombroso (1895, p. 26) analysed writings of anarchists like Merlino and Kropotkin, asking 'what is the raison d'être of the government?' Governments are not exceptionally endowed, infallible or incorruptible and when they induce unequal political rights, the majority of people will suffer, while government deputies become targets for anarchist actors, which Lombroso (1895, p. 133) called 'deputicide' (deputaticidio).

Gli Anarchici includes numerous quotes from different anarchist characters. Some of these quotes state the motivations behind the violent attacks. Lombroso used court defence speeches and newspapers like La Neue Freie Presse to investigate further anarchist 
actors, even though the veracity and reliability of the gathered data remained questionable (Lombroso, 1895, p. 138). However, Lombroso (1895, p. 76) never revealed the sources of the quotes, like that of Caserio's brother when describing Caserio's childhood behaviour. Lombroso never questioned the truthfulness and veracity of the data gathered or his sources, but looked more at the impact of that information. This indeed is in line with Horgan (2011), who favours finding the significance of what is said rather than the 'reality'.

\section{Profiling terrorists}

The risks posed by the threat of terrorism remain a major concern and keep on creating anxieties in identifying who might be the next generation of terrorist actors according to age, gender, race, religion and other characteristics that help us create the 'profile of a terrorist' (Suttmoeller, Chermak, Freilich, \& Fitzgerald, 2011). The last theme explored the question 'what is the possibility of creating profiling a terrorist? Most respondents (18 of 20) opined that profiling terrorists has limited value. Political conflicts and particular behavioural trends may indicate potential terrorist activity, but the respondents believed that no profile could perfectly fit a terrorist individual or group. All academic respondents explained that there are no 'terrorist profile' and attempted ones are only stereotypical images. The respondents agreed that terrorist profiling does not exist and it is not a viable option to mitigate terrorism.

Preconceived ethnical profiles and stereotypes label people with particular characteristics as terrorists or potential ones. The responses indicated that labelling could increase the discrimination of particular ethnic groups and consequently escalate terrorist behaviour. Only behavioural and intelligence-led profiling could provide valuable information on specific groups or individuals. This converged the views of the majority of the interviewees in stressing that every terrorist group should be tackled on its own merits. After Al Qaeda's attacks in Western countries, the terrorist profile became synonymous with someone who looks like a Muslim. But as academic respondents pointed out, 'just a few years ago the stereotype of a terrorist looked like a leprechaun [in the UK because of attacks by Irish militants] and in the future it might be something else, as it changes through time'. Sageman (2004) and Horgan (2007) also point out that researchers are still looking for common social, demographic and political backgrounds that distinguish myths from realities (see also Jacques \& Taylor, 2012; Leiken \& Brooke, 2006; Russell \& Miller, 1977; Silber \& Bhatt, 2007).

Perhaps the strong scepticism expressed by the respondents on profiling terrorists is the result of experience and research. In contrast, Lombroso was obsessed with creating both a behavioural and a physical profile of political violent actors. After studying a series of ideological passions, and the relevant political, social and economic contexts, he sustained that economic or social fanaticisms play a major role in political crimes. Lombroso $(1895$, p. 69) also stressed that this exceptional behaviour of the political criminal is derived from pure passion and honesty, which is the antithesis of the born-criminal.

In chapter seven of Gli Anarchici, titled Rei per passione (Crimes of passion), Lombroso presented his profile of the typical anarchist. The first part of this chapter describes the age, gender and other physiognomic aspects. After describing the appearance of Russian nihilists, French rebels and Italian revolutionaries, Lombroso (1895, p. 69) called the good-looking physiognomy of these individuals as 'almost anti-criminal'. As regards 
gender and age, Lombroso (1895, p. 70) echoed Régis (1890, as cited in Lombroso, 1895), and affirmed that 'women, especially those aged between 18 and 25, who are proportionately less represented in general crimes are more dominant in this kind of [political] crime'. In this age bracket, enthusiasm and selflessness were among the factors that increased the attractiveness to crime, resulting in young revolutionaries (Desmarets, 1833, as cited by Lombroso, 1895).

Lombroso also observed common behavioural characteristics among anarchist actors. For example, he highlighted an inherited political fanaticism, an exaggerated honesty in political criminals as well as the tendency of not being accompanied by accomplices during their criminal act. In support of his argument, Lombroso mentioned Charlotte Corday. Corday was an honest young woman who studied history and philosophy, and was later enlightened with the literature of Plutarch, Montesquieu and Rousseau. Imbibed by the Girondists' ideology, Corday murdered Jean-Paul Marat, a leading member of the Jacobin faction. Quoting D'Abrantés (1838), Lombroso (1895, p. 71) explained that when Corday was asked 'how such a weak and inexperienced woman could possibly kill Marat without any help from some accomplices', she answered, 'anger (indication of the violent passion) had inflamed my heart and taught me the way to pierce his heart'.

Lombroso mentioned numerous other examples of individuals who had committed serious crimes or died for their political ideals. Lombroso looked at fictitious political heroes from Dostoyevsky's novels, as well as real cases. From the trial of 50 Muscovite Socialist Revolutionaries in St. Petersburg, Lombroso quoted a female who was being prosecuted and stated, 'I will resist any sentence you may impose, because I have a faith that you do not have, I believe in the accomplishment of my ideals'. Lombroso also compared this principle of sacrificing oneself to the passionate martyrdom of Christ's followers.

These examples show how difficult it is to identify who will become a political criminal and eventually commit atrocious acts. This discussion on the passionate impetus of political criminals culminated in the case of Caserio. Lombroso studied Caserio's family background and the context in which he had been brought up, and described what he considered to be the loyal and honest character of this individual. Besides his innate epileptic nature and hyperaesthesia, the only potential criminal tendencies in Caserio were vagrancy and that he ran away from home at a young age when a man was traditionally considered attached to his land. Caserio worked as a baker and at 17 years of age he 'received the germs of anarchism'. He was indoctrinated to the extent that he killed French President Carnot (Lombroso, 1895, p. 76).

Although Lombroso looked at the physiognomy of anarchist actors, which contrasts with the respondents' standpoint, Gli Anarchici also shows that no specific indicators can accurately build a terrorist profile. Congruently, both the interviewees and Lombroso insisted that extremist ideals attract men or women, offenders or honest individuals, predominantly when influenced by the collective identity (Post, 2005) and group processes (Taylor, 2010). Further confirmations of Lombroso's study are indicated in the interview with 'Charles', who holds an extremist ideology against Muslims.

\section{An extremist perspective: applying Lombroso's viewpoint}

This section compares Charles's personal experiences and opinions with some of the themes discussed in this research, particularly with Lombroso's point of view. Charles's 
experience is an example that shows how difficult it is to identify who will be involved in extremism and who will eventually get into terrorism. Charles's involvement in an antijihad movement was unexpected. At 15 years of age, he was kicked out of home and 'ended up involved in drugs and incurred great debts'. From his teenage years until his early twenties, Charles was in and out of prison several times. At 21, Charles experienced 'a very powerful spiritual conversion that changed [his] life'. Charles described this experience as 'angelic and a big testimony of God's powers', which changed him from an underworld criminal into a fervent Christian. As a Christian and a law-abiding person, Charles thought it was his duty to report the misdeeds of the Muslim community in his neighbourhood.

There were Muslims selling heroin and crack cocaine next door from where I was living. So I went to the police. They were arrested ... [but] they found out that it was me who gave the information. They threatened me and from then on, I had the choice of hiding and running away from these people or of standing up to them. So I stood up to them and started speaking out.

Following this experience, Charles became 'an extreme Muslim hater'. He left his shop and home, and travelled to Israel and the USA. He met people who supported his extremist ideas and encouraged him to document the threats he suffered. Charles set up an Internet blog and started to write profusely about his anti-jihadist ideologies, which he described as 'relevant, real and personal'. Calling himself a 'keyboard warrior', Charles wanted the world to be knowledgeable about these coercive forces. Soon he became involved in a movement whose members shared the same principles. He described this movement as, 'a large group of people share the same belief about the threat we face. So I got involved in it'.

Involved in the foundation of a right-wing extremist group, Charles took the role of a spiritual leader. He explained that this extremist movement keeps on growing and it is affiliated with other groups around the world.

The movement as a whole is made up of different organisations from around the world. In Europe it is evolving and what happened now [the terrorist attack] is going to separate the good from the bad. The fundamentals of the movement as a whole are right and nobody can deny the rights of those people to say what they say and believe what they believe because it is true and they can justify it, stand by it and prove it.

The social networks that support similar extremist ideologies reminded the importance of understanding the root causes of terrorism. Also as indicated by the respondents, security entities should widen their monitoring scope and start observing other extremist groups besides extremist Muslim factions. A case in point would have been to monitor and attempt to understand the terrorist who declared to be the mentee of Charles. According to Charles, this sympathizer was motivated by problems created by the mass immigration of Muslims that angered right-wing extremists, and some actors 'channelled this rage into murderous acts'. Even though Charles was identified as 'mentor' by this terrorist, he denied any connection with any violent actor. He declared that his role was to defend Christianity and he could only inspire the killing of radical Islamists:

I looked at [this terrorist's] hidden inspiration ... but then I took a step back afterwards and said no there is no way this could relate to me. What [this actor] did was a devilish act but dressed up in Christianity. He murdered children in the name of Jesus Christ but Jesus 
Christ is not going to sit back and explain why this happened. I have been placed in this situation to defend Christianity, to defend the name of Jesus Christ. Maybe I was his inspiration or I wasn't. If he had killed lots of Islamic fundamentalists I could imagine and understand that I was his inspiration, but he killed lots of innocent individuals.

It was not possible to explore further the link between Charles and this terrorist, but since a violent actor described Charles as his 'mentor', Charles had an influential role and became an inspiring figure. Another linking factor between Charles and this extremist actor was the use of Templar symbols. The Templars were Charles's role model in the defence of Europe against the Muslim jihad. Charles wore tattoos of a Templar cross and the Star of David on his wrists and revealed the importance that:

These tattoos represent my bit of solidarity with Israel and the Jewish people. The whole Islamic world is against Israel; the birthplace of Christianity and that part of the world and the holocaust almost destroyed the Jewish race. It's like kind of my position on that issue. Similarly, the Templar cross shows my position on the same issue.

Following Lombroso's thematic issues, Charles's behaviour, criminal history, prolific writing, his need to get his message to the general public as well as his influence as a 'mentor' take a different meaning. When one notes the constant references to the struggle between Christians and Muslims in Charles's account and in the motivations of his extreme-right connections, these reflect Lombroso's $(1895$, p. 8) portrayal of religion as a 'lightning conductor of fanaticism'. Although the reactions of Charles and his 'mentored' terrorist actor to the Islamification of their country were extremely diverse, they both aimed to draw the general public's and the government's attention to their religious and political ideologies against Muslims. Thus, even without considering any physiognomic aspects, Charles's 'profile' would have been of immense interest to Lombroso, particularly with regard to his tattoos, lack of education, history of juvenile delinquency, abuse of drugs and the fact that he had left home in his teenage years. Tattoos do not make a person a criminal, but 'one cannot miss the frequent sign of the born-criminal - the tattoo' (Lombroso, 1895, p. 38). Charles's tattoos of the Templar cross and the Star of David were not simply decorative. They were directly linked to his anti-jihadist ideology - a clear sign of how the Templars served as an inspiration of his fight against Muslims.

Another interesting aspect that would have drawn Lombroso's attention to Charles's case is his 'angelic experience'. Following his alleged supernatural experience with angels, Charles suddenly converted from a criminal into an ardent Christian. Lombroso (1895, p. 48) delineated how 'the presence of vanity, religiosity, realistic hallucinations, megalomania, intermittent geniality together with the impulsiveness of epileptics and hysterics, create innovative religious persons and politicians'. Lombroso $(1895$, p. 48) quoted the British psychiatrist Maudsley, who believed that 'Mohammed had an attack of epilepsy during his first vision or revelation, and deceived by it or deceitfully he used his illness to pretend he was inspired from heaven'. Lombroso considered these epileptic episodes as congenital and as a side effect of alcohol abuse. In Charles's case, Lombroso would have inquired whether his parents had had similar experiences and whether Charles had been under the effect of drugs when this happened. Charles met different persons who influenced his trajectory towards right-wing extremism and who directed him to write down his experiences and thoughts about the subject in his online blog. Charles became a prolific writer on the subject. Among the different categories of anarchists, Lombroso 
described $i$ mattoidi (mattoids) as inexhaustible writers. For example, Passanante consumed reams of paper to publish his thoughts, which he considered more important than his own life. Similarly, Charles 'the keyboard warrior' used the Internet to spread his message.

Media was always an attractor to sympathizers and potential actors. Lombroso inquired how anarchists allured sympathizers using journals and books. Lombroso also noted how anarchists used newspapers and journals to influence the general public. For example, although in the nineteenth-century cameras were not as easily available as nowadays, Vaillant ensured that the newspapers published a photo of the French parliament chamber before the explosion of his bomb. Conscious of this synergistic effect that the media and anarchist terrorists had on each other, Lombroso asserted:

$\ldots$ it is not wise to believe that it is possible and very easy to subdue the press because it is the Proteus of modern life. The press became too fine, agile and powerful to control; it is the same like trying to put the wind in chains particularly for a Government without an immense coercive power like the Russian Government. Other than that, even if the anarchist press is suppressed, propaganda will equally contribute because propaganda is mostly spread orally rather than using the press and addresses an ignorant and gross public. (Lombroso, 1895, p. 123)

In today's world, ideological influences are still passed orally in training grounds like universities or prisons (Taylor, 1988), but material is passed on to sympathizers using books and manifestos and the Internet. Internet is becoming increasingly instrumental in the mushrooming of small terrorist cells and individual terrorists (see Sageman, 2008; Weinmann, 2006). The Internet provides access and connections to individuals and communities with similar ideologies that help to instigate and guide them to carry out activities without the need to meet in person (Pantucci, 2011). As Charles's work served as an inspiration to the terrorist actor, Charles became a sort of modern 'Old Man of the Mountain' that disseminates inspiring extremist ideas.

Features like the use of symbols, the strong connections with religion, the 'angelic experience', the criminal history and his being a prolific writer that influenced people would have rendered Charles a perfect specimen for a study by Lombroso. This also demonstrates that though the unorthodox methods used by Lombroso may be attacked on different fronts, he aimed to understand political crime and anarchism in their totality and to sustain his arguments with 'empirical data'. Thus, though contemporary research paradigms are different from those followed by Lombroso, he could still be considered a forerunner in the research of political violence and terrorism.

\section{Concluding thoughts}

The purpose of this research was mainly to make past and present research meet on a number of contemporary and contentious terrorism issues. Terrorism is often considered to be a contemporary ubiquitous scourge that can target any country. Yet Cesare Lombroso's work provides evidence of political, social and legal issues as the root causes of anarchist terror at the end of the nineteenth century. This paper provided seven thematic bridges between Lombroso's thoughts and theories on political crime and the views of twenty contemporary experts that included policy-makers, security professionals and 
academics. These two different research paradigms may look at the ever-evolving phenomenon of terrorism and political violence from two distinct lenses, but both demonstrate that there are still numerous gaps in drafting policies and researching political crime and terrorism, and these lacunae did not change much through the centuries (see Table 2).

Table 2. Bridging current professional view with Lombroso's theories.

\begin{tabular}{|c|c|c|}
\hline Theme & $\begin{array}{l}\text { Professional interviewees } \\
\text { (contemporary views) }\end{array}$ & $\begin{array}{c}\text { Lombroso's viewpoint } \\
\text { (nineteenth-century views) }\end{array}$ \\
\hline $\begin{array}{l}\text { (1) Definition of } \\
\text { terrorism }\end{array}$ & The use of violence for political objectives. & $\begin{array}{l}\text { The violent harm to laws meant to preserve } \\
\text { the political, economic and social system. }\end{array}$ \\
\hline $\begin{array}{l}\text { (2) Security and } \\
\text { terrorism risk } \\
\text { management }\end{array}$ & $\begin{array}{l}\text { The terrorist threat is middle to high. The } \\
\text { public's reaction to the terrorist threat is } \\
\text { unknown and difficult to determine since it } \\
\text { varies with the culture. Security entities } \\
\text { tend to be secretive and it is difficult to } \\
\text { determine the real threat level. A higher }\end{array}$ & $\begin{array}{l}\text { Despotic governments use brutal force to } \\
\text { control citizens. Governments used the } \\
\text { anarchist threat for their purposes and } \\
\text { agendas. Entities like the police force are in } \\
\text { need of these threats to remain active. }\end{array}$ \\
\hline
\end{tabular}

(3) Counterterrorism and policy-making

(4) Imprisonment and rehabilitation

(5) Identifying terrorism research

(6) Research methods in terrorism

(7) Profiling terrorists
Punishment for terrorism should include imprisonment but combined with educational reforms that facilitate reintegration into society.

Combining academic research with intelligence analysis is indispensable to hinder terrorism.

A multidisciplinary perspective can provide a more holistic perspective of the phenomenon. It is important to resort to primary sources to gather data. Both statistics and interviews are useful methodologies in researching terrorism, though the two have weaknesses.

Creating a generic profile for terrorist is an illusion. However, it is possible to create a behavioural or intelligence-led profile, which would be based on observations of specific terrorist groups or individuals.
To counter anarchist terrorism, there should be a multi-agency approach. Police should be more intelligence-led and should document photos of any suspicious individuals. Whoever is arrested should be locked in asylums or sent to distant islands (transportation). Lombroso also recommended changes in religions and classical education that expressed admiration towards violence.

The punishment for political crimes should not include violence as this creates 'martyrs'. Punishment should include deportation; solitary confinement; exile; pecuniary penalties; suspension from or loss of offices (in case of public officers) and removal of political rights. Martyrs tend to become icons or idols, and their image is used to attract more recruits.

Lombroso analysed political conflicts, economic depressions and social difficulties to understand the contexts. Also he studied anarchist personalities, their backgrounds and psycho-behavioural reactions to comprehend better why particular individuals decide to follow the anarchist ideology.

Used various disciplines to inquire the anarchist actors. Lombroso referred to both qualitative research (e.g. discourse analysis) and to quantitative research (e.g. Table 1 and Figure 1).

Creating the profile of the political criminal was very important. The physical characteristics indicated that political criminals are the antithesis of the borncriminals. Political criminals are driven by the passion for their ideology and it is more difficult to determine who will become an extremist actor. 
Translating, analysing and presenting Lombroso's original work in this paper contribute to increase the academic repertoire of criminologists, while shedding light on how Lombroso contributed to the research of terrorism and political violence. In the past, researchers discarded Lombroso, and in some cases current academics still do. However, Lombroso's thoughts, research methods and theoretical contributions to criminology and political studies from la scuola positiva (the positivist school) on anarchists attest their potential contribution to the study of various areas in this field, namely the effect of oppressive policies; the catalysts of terrorist attacks; common behaviours among fanatical extremists and how to mitigate terrorism through non-violent means. Gli Anarchici also indicates that terrorism and other political crimes were already under the academic microscope as from the origins of criminology.

In conclusion, this study served to portray the current understandings on topical and contentious concerns on terrorism. Second, the results suggested that Lombroso, as the father of criminology, placed political violence and terrorism under the microscope as from the beginning of criminology. The outcome from Gli Anarchici also postulated prophylactic recommendations that are much aligned with contemporary perspectives. Perhaps in deference to the way in which Lombroso's thinking still has an enormous relevance in today's terrorist environment, we should leave the very last words to Gli Anarchici:

Per carità, non imitiamoli, non siamo ciechi al par di questi; popolo che in mezzo a tante vergogne, a tanti vizi, non abbiamo avuto mai quello dell'intemperanza politica, non guastiamo le nostre buone tradizioni, non incrudeliamo fanciullescamente contro il fenomeno dell'anarchia, a rischio d'ingrandirla e renderla più feroce invece di ricercarne e curarne radicalmente le cause. (Lombroso, 1895, p. 137)

Please, we should not imitate them and be blind like them. In the midst of much shame and so many vices we never had that political intemperance to degrade our good traditions and face the phenomenon of anarchy with childish incredulity at the risk of magnifying it, making it more ferocious and violent. Instead we have to invest in research and radically cure its causes. (Lombroso, 1895, p. 137)

\section{Note}

1. It is observed that cholera is more inclined to hit the poorest and filthiest neighbourhoods in the city, indicating where to concentrate preventive treatment. Similarly, anarchy attacks in less well-governed countries. Therefore, anarchy could be the result of apathy or a sign of bad government that stimulates improvement.

\section{Disclosure statement}

No potential conflict of interest was reported by the author.

\section{Notes on contributor}

Calafato Trevor is a Lecturer at the University of Malta in the Department of Criminology. Before moving to university, he was a probation officer for more than six years, where he was also in charge of the health, safety and security of the Department of Probation. He holds a M.Sc. in Security and Risk Management at the University of Leicester. He studied the potential responses and preventive measures of terrorist incidents in Malta. He holds a PhD from the University of Sheffield that 
focuses on security measures and terrorism research. He has published articles and book chapters on security, terrorism, criminology and criminal justice, and on Cesare Lombroso.

\section{References}

Alonso, R. (2006). The IRA and armed struggle. London: Routledge.

Arquilla, J., \& Ronfeldt, D. (2001). The advent of Netwar (revisited). Retrieved July 1, 2009, from http:// www.rand.org/pubs/monograph_reports/MR1382/MR1382.ch1.pdf.

Baeyer-Kaette, W., Classens, von D., Feger, H., \& Neihardt, F. (Eds.). (1982). Analysen zum terrorimsus 3: Gruppenprozesse. Darmstadt: Verlag.

Banks, C. (2013). Criminal justice ethics: theory and practice (3rd ed.). London: Sage Publications.

Berko, A. (2007). The path to paradise: The inner world of suicide bombers and their dispatchers. Washington, DC: Potomac Books.

Berrebi, C., \& Klor, E. F. (2006). On terrorism and electoral outcomes: Theory and evidence from the Israeli-Palestinian conflict. Journal of Conflict Resolution, 50(6), 899-925.

Bjørgo, T. (Ed.). (2005). Root causes of terrorism: Myths, reality and ways forward. New York, NY: Routledge.

Bloom, M. (2005). Dying to kill: The allure of suicide terror. New York, NY: Columbia University Press.

Bonanate, L., Oldani, A., \& Migliorino, L. (1979). La violenza politica nel mondo contemporaneo: bibliografia internazionale sul terrorismo, i movimenti di ribellione, la guerriglia urbana, le guerre di liberazione, le lotte antimperialistiche : la mappa del terrorismo nel mondo contemporaneo [Political violence in the contemporary world: International bibliography on terrorism, movements of rebellion, guerrilla warfare, wars of liberation, anti-imperialistic struggles: The map of terrorism in the contemporary world]. Milan: Franco Angeli Editore.

Braun, V., \& Clarke, V. (2006). Using thematic analysis in psychology. Qualitative Research in Psychology, 3, 77-101.

Bryan, D. (2012). Is terrorism still a useful analytical term or should it be abandoned? NO: A landscape of meaning: constructing understandings of political violence from the broken paradigm of 'terrorism'. In R. Jackson \& S. J. Sinclair (Eds.), Contemporary debates on terrorism (pp. 17-23). London: Routledge.

Calafato, T. (2013). Gli Anarchici and Lombroso's theory of political crime. In P. Knepper \& P. J. Ysetehede (Eds.), The Cesare Lombroso handbook (pp. 47-71). London: Routledge.

Chatterjee, S., \& Abkowitz, M. D. (2011). A methodology for modeling regional terrorism risk. Risk Analysis, 31(7), 1133-1140. doi:10.1111/j.1539-6924.2010.01565

Cilluffo, F., \& Saathoff, G. (2006). Out of the shadows: Getting ahead of prisoner radicalization. Report by George Washington University, Homeland Security Policy Institute, and University of Virginia, Critical Incident Analysis Group. Retrieved June 13, 2012, from http://www.pbs.org/weta/ crossroads/incl/Out-of-the-Shadows.pdf.

Coolsaet, R., \& de Swieland, T. S. (2008). Epilogue: Zeitgeist and (de-)radicalisation. In R. Coolseat (Ed.), Jihadi terrorism and the radicalisation challenge in Europe (pp. 259-268). Hampshire: Ashgate Publishing Ltd.

Crenshaw, M. (2001). Theories of terrorism: Instrumental and organizational approaches. In D. C. Rapoport (Ed.), Inside terrorist organisations (pp. 13-31). London: Frank Cass.

D'Abrantés, L. J. (duchesse d'). (1838). Vite e ritratti delle donne celebre d'ogni tempo e d'ogni paese. Napoli: Stabilimento Letterario Tipografico dell'Atneo.

Daftary, F. (2008). The assassin legends: Myths of the Isma'ilis. London: I.B. Tauris \& Co Ltd.

Daly, J. (2002). Political crime in late imperial Russia. The Journal of Modern History, 74, 62-100.

Daly, J., Kellehear, A., \& Gliksman, M. (1997). The public health researcher: A methodological approach. Melbourne, Australia: Oxford University Press.

Denzin, N. K., \& Lincoln, Y. S. (Eds.), (2008). Collecting and Interpreting Qualitative Materials (3rd ed.). London: Sage Publications.

Desmarets, P. M. (1833). Témoignages historiques: Quinze ans de haute police sous Napoléon. Paris: Alphonse Levavasseur, Libraire. 
Dolnik, A. (2011). Conducting field research on terrorism: A brief primer. Perspectives on Terrorism, 5 (2), 3-35. Retrieved April 9, 2012, from http://www.terrorismanalysts.com/pt/index.php/pot/index.

Dubois, F. (1893). Le perile anarchiste, France. In C. Lombroso (Ed.), Gli Anarchici. Torino: Bocca.

English, R. (2009). Terrorism: How to respond. Oxford: Oxford University Press.

Europol. (2012). TE-SAT: EU terrorism situation and trend report. European Police Office. Retrieved from www.europol.europa.eu.

Fereday, J., \& Muir-Cochrane, E. (2006). Demonstrating rigor using thematic analysis: A hybrid approach of inductive and deductive coding and theme development. International Journal of Qualitative Methods, 5(1), 1-11. Retrieved from http://www.ualberta.ca/ iiqm/backissues/5_1/ pdf/fereday.pdf

Finn, J. E. (2010). Counterterrorism regimes and the rule of law: The effects of emergency legislation on separation of powers, civil liberties and other fundamental constitutional norms. In $M$. Crenshaw (Ed.), The consequences of counterterrorism (pp. 33-93). New York, NY: Russell Sage Foundation.

Fraihi, T. (2008). (De-)escalating radicalisation: The debate within Muslim and Immigrant Communities. In R. Coolseat (Ed.), Jihadi terrorism and the radicalisation challenge in Europe (pp. 131-138). Hampshire: Ashgate Publishing Ltd.

Gibson, M., \& Rafter, N. H. (translators). (2006). Criminal man: Translated and with a new introduction. Durham: Duke University Press.

Gordon, A. (2010). Can terrorism become a scientific discipline? A diagnostic study. Critical Studies on Terrorism, 3(3), 437-458.

Gunaratna, R. (2011, April). Terrorist rehabilitation: A global imperative. Journal of Policing, Intelligence and Counter Terrorism, 6(1), 65-82.

Gunning, J. (2007). Babies and bathwaters: Reflecting on the pitfalls of critical terrorism studies. European Political Science, 6, 236-243.

Gupta, D. K. (2008). Understanding terrorism and political violence: The life cycle of birth, growth, transformation, and demise. London: Routledge.

Gupta, D. K. (2012). Is terrorism the result of root causes such as poverty and exclusion? Yes: Do structural factors explain terrorism? In R. Jackson \& J. S. Sinclair (Eds.), Contemporary debates on terrorism (pp. 107-113). London: Routledge.

Gupta, D. K., \& Mundra, K. (2005). Suicide bombing as a strategic weapon: An empirical investigation of Hamas and Islamic Jihad. Terrorism and Political Violence, 17(4), 573-598.

Gurr, T. R. (1970). Why men rebel. Princeton, NJ: Princeton University Press.

Hamel, M., \& Marie, A. (translators). (1896). Les anarchistes. Paris: Flammarion.

Hoffman, B. (1998). Inside terrorism. New York, NY: Columbia University Press.

Hoffman, B. (2006). Inside terrorism: Revised and expanded edition. New York, NY: Columbia University Press.

Horgan, J. (2005a). The social and psychological characteristics of terrorism and terrorists. In T. Bjørgo (Ed.), Roots of terrorism: Myths, reality and ways forward (pp. 106-126). London: Routledge.

Horgan, J. (2005b). The psychology of terrorism. London: Routledge.

Horgan, J. (2007). Understanding terrorist motivation: A socio-psychological perspective. In M. Ranstorp (Ed.), Mapping terrorism research: State of the art, gaps and future direction (pp. 106-128). London: Routledge.

Horgan, J. (2008). Interviewing terrorists: A case for primary research. In H. Chen, E. Reid, J. Sinai, A. Silke, \& B. Ganor (Eds.), Terrorism informatics: Knowledge management and data mining for homeland security (pp. 73-99). New York, NY: Springer.

Horgan, J. (2009). Walking away from terrorism: Accounts of disengagement from radical and extremist movements. London: Routledge.

Horgan, J. (2011). Interviewing the terrorists: Reflections on fieldwork and implications for psychological research. Behavioural Sciences of Terrorism and Political Aggression, iFirst Article, 1-17. doi:10.1080/19434472.2011.594620

Jackson, R. (2009). The study of terrorism after 11 September 2001: Problems, challenges and future developments. Political Studies Review, 7, 171-184. 
Jackson, R. (2011). In defence of 'terrorism': Finding a way through a forest of misconceptions. Behavioral Sciences of Terrorism and Political Aggression, 3(2), 116-130. London: Routledge, Taylor \& Francis Group. doi:10.1080/19434472.2010.512148

Jacques, K., \& Taylor, P. J. (2012). Myths and realities of female-perpetrated terrorism. Law and Human Behaviour, 1-10. Retrieved from http://www.apa.org/pubs/journals/releases/lhb-ofp-jacques.pdf.

Jager, H., Schmidtchen, G., \& Sulllwold, L. (Eds.). (1981). Analysen zum terrorimsmus 2: Lebenslaufanalysen. Darmstadt: Verlag.

Jamieson, A. (1990). Identity and morality in the Italian Red Brigades. Terrorism and Political Violence, 2, 508-520.

Joffe, H., \& Yardley, L. (2004). Content and thematic analysis. In D. E. Marks, \& L. Yardley (Eds.), Research methods for clinical and health psychology (pp. 56-68). London: Sage Publications.

Jupp, V. (2003). Methods of criminological research. London: Routledge.

Kellen, K. (1982). On terrorists and terrorism. Retrieved June 29, 2011, from http://www.rand.org/ content/dam/rand/pubs/notes/2005/N1942.pdf.

Kunreuther, H. (2002). Risk analysis and risk management in an uncertain world. Risk Analysis, 22(4), 655-664.

Kurella, H. (translator). (1895). Die Anarchisten. Verlagsantalt und Druckerei: Hamburg.

Kydd, A. H., \& Walter, B. F. (2006). The strategies of terrorism. International Security, 31, 49-80.

LaFree, G., Dugan, L., Xie, M., \& Singh, P. (2012). Spatial and temporal patterns of terrorist attacks by ETA 1970 to 2007. Journal of Quantitative Criminology, 28, 7-29.

Laqueur, W. (2001). Left, right and beyond: The changing face of terror. In J. Hoge, Jr., \& G. Rose (Eds.), How did this happen? Terrorism and the new war (pp. 71-82). Oxford: Public Affairs.

Leiken, R., \& Brooke, S. (2006). The quantitative analysis of terrorism and immigration: An initial exploration. Terrorism and Political Violence, 18, 503-521.

Lerner, J., Gonzalez, R., Small, D., \& Fischhoff, B. (2003). Effects of fear and anger on perceived risks of terrorism: A national field experiment. Psychological Science, 14, 144-150.

Lombroso, C. (1895). Gli Anarchici: seconda edizione con aggiunte (2nd ed.). Torino: Bocca.

Lombroso, C., \& Horton, H. P. (1912). Crime: Its causes and remedies. Boston, MA: Little, Brown and Company.

Lombroso, C., \& Laschi, R. (1892). Le crime politique et les révolutions par rapport au droit, Bouchard, A., Vols. 2, pp. 1: v-vi.

Mason, J. (2001). Linking qualitative and quantitative data analysis. In A. Bryman, \& R. G. Burgess (Eds.), Analyzing Qualitative Data (pp. 89-110). Oxon: Routledge.

Maxfield, M. G., \& Babbie, E. R. (2011). Research methods for criminal justice and criminology, (6th ed.). United Kingdom: Wadsworth Cengage Learning.

McAllister, B., \& Schmid, A. P. (2011). Theories of terrorism. In A. P. Schmid (Ed.), The Routledge handbook of terrorism research (pp. 201-271). London: Routledge.

McCauley, C. (2007). Psychological issues in understanding terrorism and response on terrorism. In B. Bongar, L. M. Brown, L. E. Beutler, J. N. Breckenridge, \& P. G. Zimbardo (Eds.), Psychology of terrorism (pp. 13-31). Westport: Oxford University Press.

Merari, A. (2005). Palestinian resistance and 'suicide bombing': Causes and consequences. In T. Bjørgo (Ed.), Root causes of terrorism: Myths, reality and ways forward (pp. 70-87). London: Routledge.

Mottahedeh, N. (1998). Mutilated body of the modern nation: Qurrat al-'Ayn's unveiling and the Persian Massacre of the Bábís. Comparative Studies of South Asia, Africa and the Middle East, $18(2), 38-50$.

Mueller, J. (2006). Overblow: How politicians and the terrorism industry inflate national security threats, and we believe them. New York, NY: Free Press.

Neumann, P. R. (2010). Prisons and terrorism: Radicalisation and de-radicalisation in 15 countries. The International Centre for the Study of Radicalisation and Political Violence. Retrieved June 13, 2010, from http://icsr.info/publications/papers/1277699166PrisonsandTerrorismRadicalisationandDera dicalisationin 15Countries.pdf.

Pantucci, R. (2011). A typology of lone wolves: Preliminary analysis of lone Islamist terrorists. London: ICSR. 
Pape, R. (2003). The strategic logic of suicide terrorism. American Political Science Review, 97(3), 343-361.

Post, J. M. (1984). Notes on a psychodynamic theory of terrorist behavior. Terrorism, 7, 241-256.

Post, J. M. (1990). Terrorist psycho-logic: Terrorist behaviour as a product of psychological forces. In W. Reich (Ed.), Origins of terrorism: Psychologies, ideologies, theologies, states of mind (pp. 25-42). New York, NY: Cambridge University Press.

Post, J. M. (2005). The psychological roots of terrorism. In The International Summit on Democracy, Terrorism and Security, 8-11 March, Madrid, Addressing the causes of terrorism: The Club de Madrid series on democracy and terrorism. Madrid: Club de Madrid, pp. 7-12.

Post, J. M., Sprinzak, E., \& Denny, L. (2003). The terrorists in their own words: Interviews with 35 incarcerated Middle Eastern terrorists. Terrorism and Political Violence, 15, 171-184.

Rafter, N. (Ed.). (2009). The origins of criminology: A reader. Oxon: Routledge.

Ramadan, T. (2006). The global ideology of fear. In R. Coolsaet (Ed.), Jihadi terrorism and the radicalisation challenge in Europe (pp. 13-24). England: Ashgate Publishing Ltd.

Régis, E. (1890). Les régicides dans l'histoire et dans le présent. Lyon: A. Storck.

Reich, W. (Ed.). (1998). Origins of terrorism: Psychologies, ideologies, theologies, states of mind. Baltimore: The John Hopkins University Press.

Rice, P., \& Ezzy, D. (1999). Qualitative research methods: A health focus. Melbourne: Oxford University Press.

Russell, C. A., \& Miller, B. H. (1977). Profile of a terrorist. Military Review, 57(8), 21-34.

Sageman, M. (2004). Understanding terror networks. Philadelphia: University of Pennsylvania Press.

Sageman, M. (2008). Leaderless jihad: Terror networks in the twenty-first century. Philadelphia: University of Pennsylvania Press.

Schmid, A. P. (1997). The problems of defining terrorism. In M. Crenshaw \& J. Pimlott (Eds.), Encyclopedia of World Terrorism (Vol. 1, pp. 12-22). New York: M. E. Sharpe.

Schmid, A. P. (2004). Terrorism: The definitional problem. Case Western Reserve Journal of International Law, 36(2-3), 375-419.

Schmid, A. P. (2007). Why terrorism? Addressing the conditions conducive to the spread of terrorism. Document prepared by the Secretariat Counter-Terrorism Task Force Directorate General of Legal Affairs. Retrieved January 10, 2014, from http://www.coe.int/t/dlapil/codexter/Source/ conf/Conf\%20Prev\%20Terr\%20\%282007\%29\%2018\%20rev\%20E\%20only\%20Schmid\%20presen tation.pdf

Schmid, A. P. (Ed.). (2011). The Routledge handbook of terrorism research. Abingdon: Routledge. DOI: 10.1111/1478-9302.12028_41

Schmid, A. P., \& Jongman, A. J. (1988, 2008). Political terrorism: A new guide to actors, authors, concepts, data bases, theories \& literature. London: Transaction.

Schuster, M. A., Stein, B. C., Jaycox, L. H., Collins, R. L., Marshall, G. N., Elliott, M. N., ... Berry, S. H. (2001). A national survey of stress reactions after the September 11, 2001, terrorist attacks. New England Journal of Medicine, 345, 1507-1512.

Silber, M. D., \& Bhatt, A. (2007). Radicalization in the west: The Homegrown threat. New York City Police Department. Retrieved August 15, 2012, from http://www.nypdshield.org/public/SiteFiles/ documents/NYPD_Report-Radicalization_in_the_West.pdf.

Silke, A. (Ed.). (2003). Terrorists, victims and society: Psychological perspectives on terrorism and its consequences. Chichester: John Wiley.

Silke, A. (Ed.). (2004). Research on terrorism: Trends, achievements and failures. London: Frank Cass.

Silke, A. (2001). The devil you know: Continuing problems with research on terrorism. Terrorism and Political Violence, 13, 1-14.

Silke, A. (2008). Research on terrorism. In H. Chen, E. Reid, J. Sinai, A. Silke, \& B. Ganor (Eds.), Terrorism informatics: Knowledge management and data mining for Homeland security (pp. 27-50). New York, NY: Springer Publications.

Sinai, J. (2007). New trends in terrorism studies: Strengths and weaknesses. In M. Ranstorp (Ed.), Mapping terrorist research: State of the art, gaps and future direction (pp. 31-50). London: Routledge. 
Sinai, J. (2008). Resolving a terrorist insurgency by addressing its root causes. In H. Chen, E. Reid, J. Sinai, A. Silke, \& B. Ganor (Eds.), Terrorism informatics: Knowledge management and data mining for Homeland security (pp. 101-114). New York, NY: Springer.

Smelser, N. J., \& Mitchell, F. (Eds.). (2002). Terrorism: Perspectives from the behavioural and social sciences. Washington, DC: The National Academies Press.

Sottile, A. (1938). Le terrorisme international. Recueil des Cours de l'Academie de Droit International de la Haye, 3, 87-184 (Republished with the same title by Paris Sirey, 1939).

Stern, J. (1999). The ultimate terrorists. Cambridge, MA: Harvard University Press.

Stump, J. L., \& Dixit, P. (2013). Critical terrorism studies: An introduction to research methods. London: Routledge.

Suttmoeller, M., Chermak, S., Freilich, J. D., \& Fitzgerald, S. (2011). Terror groups and radicalization: Radicalization and risk assessment. In L. W. Kennedy \& E. F. McGarrell (Eds.), Crime and terrorism risk: Studies in criminology and criminal justice (pp. 80-96). London: Routledge.

Taarnby, J. M. (2005). Recruitment of Islamist terrorists in Europe: Trends and perspectives. Research Report funded by the Danish Ministry of Justice. Retrieved June 28, 2012, from http://www. justitsministeriet.dk/sites/default/files/media/Arbejdsomraader/Forskning/Forskningspuljen/2011/ 2005/Rekruttering_af_islamistiske_terrorister_i_Europa.pdf.

Taylor, M. (1988). The terrorist. London: Brassey's Defence.

Taylor, M. (2010). Is terrorism a group phenomenon? Aggression and Violent Behavior, 15, 121-129.

Taylor, M., \& Horgan, J. (2006). A conceptual framework for addressing psychological process in the development of the terrorist. Terrorism and Political Violence, 18, 585-601. UK: Taylor and Francis Group.

Taylor, M., \& Quayle, E. (1994). Terrorist lives. London: Brasseys.

Townsend, C. (2002). Terrorism: A very short introduction. Oxford: Oxford University Press.

Useem, B., \& Clayton, O. (2009). Radicalization of U.S. prisoners. Criminology \& Public Policy, 8(3), 561-592.

Waciorski, J. (1939). Le terrorisme politique. Paris: Pedone.

Weinmann, G. (2006). Terror on the Internet. Washington, DC: United States Institute of Peace Press. Wilkinson, P. (2001, 2006a, 2011). Terrorism versus democracy: The liberal state response. London: Frank Cass.

Wilkinson, P. (2006b). Terrorism. In M. Gill (Ed.), The handbook of security (pp. 328-357). London: Palgrave Macmillan.

Wilkinson, P. (2012). Is terrorism still a useful analytical term or should it be abandoned? YES: The utility of the concept of terrorism. In R. Jackson \& S. J. Sinclair (Eds.), Contemporary debates on terrorism (pp. 9-16). London: Routledge.

Young, R. (2006). Defining terrorism: The evolution of terrorism as a legal concept in international law and its influence on definitions in domestic legislation. Retrieved June 27, 2011, from http:// lawdigitalcommons.bc.edu/cgi/viewcontent.cgi?article=1054\&context=iclr\&sei-redir=1\#search= \%22reuven\%20young\%20defining\%20terrorism\%20evolution\%20legal\%20concept\%22.

Zulaika, J. (1996). The anthropologist as terrorist. In C. Nordstrom \& A. C. G. M. Robben (Eds.), Fieldwork under fire: Contemporary studies of violence and culture (pp. 206-223). Berkeley: University of California Press. 